DOI: $\underline{10.15679 / b j w r . v 2 i 1.22}$

\title{
GENETIC VARIATION WITHIN AND AMONG BROWN HARE (LEPUS EUROPAEUS PALLAS, 1778) POPULATIONS IN SERBIA AS INFERRED FROM MICROSATELLITES)
}

\author{
Djan M. ${ }^{1}$, Veličković $N .{ }^{1}$, Stefanović M. ${ }^{1}$, Marković $V .{ }^{2}$, Obreht Vidaković D. ${ }^{1}$, Vapa $L j .{ }^{1}$
}

Summary: The European brown hare (Lepus europaeus Pallas, 1778) is the only Lepus species that can be found in Serbia and Balkan Peninsula, where it represents an important game species. Previous analyses of brown hares in Serbia based on allozyme and mtDNA sequence variability revealed moderate genetic diversity and indicated possible population structuring in the region. The aim of this study is to detect population genetic diversity and structure in brown hares from Serbia using microsatellites. Material and Methods: A total number of 157 brown hares were collected from six different regions in Serbia and polymorphism of six microsatellite loci was analyzed. Following computer packages were used for the data analyses: ARLEQUIN, STRUCTURE, GENETIX, BOTTLENECK and NEWHYBRIDS.Results: A total number of 81 alleles at 6 loci were found. The highest number of alleles per locus was found at Lsa2 microsatellite loci (20), while the lowest number of alleles was present at loci Sat5 and Lsa3 (9), with an average of 13.5 alleles/locus in total sample. Different statistical approaches revealed that brown hare population from Serbia is structured into two genetic subunits (i.e., subpopulations). First subpopulation, named Northern-Central-Eastern (NCE) Serbia consists of five initially defined groups (Bačka, Banat, Srem, Northern-Central Serbia and Northern-Eastern Serbia) while second subpopulation comprised of individuals from Northern-Western (NW) Serbia. Higher values of genetic diversity parameters were found in NCE Serbia subpopulation compared to NW Serbia subpopulation. Conclusion: Observed genetic differentiation should be considered in future brown hare management strategies and consider those subpopulations as separate management units, in order to preserve existing genetic diversity and to avoid further reduction of genetic variability in NW Serbia subpopulation or human mediated admixtures which can disturb present gene pools..

Key words: genetic diversity, Lepus europaeus, microsatellites, Serbia.

\section{Introduction}

The European brown hare (Lepus europaeus Pallas, 1778) is an important game species. It has a range that includes palearctic, nearctic, oriental and neotropical regions. In Europe, L. europaeus occurs throughout the continent and extends towards Central Asia (Thulin et al., 1997; Suchentrunk et al., 2003; Fickel et al., 2005). It is the only Lepus species that can be found in Serbia and in the Balkan peninsula (Suchentrunk et al., 2000; Mamuris et al., 2001; Kasapidis et al., 2005; Stamatis et al., 2009). The brown hare adapted successfully to the agricultural landscape and now can be found in open farmland all over its range.

Species of the lagomorph genus Lepus show no differentiation among each other in genetic characters such as chromosome number and karyotype banding (Robinson et al., 1983), and very little differentiaton in allozyme markers (Hartl et al., 1993; Suchentrunk et al., 1999, 2000; Ben Slimen et al., 2006, 2007; Vapa et al., 2007). The employment of microsatellite markers provided better insight into population genetic diversity and structure in different Lepus species across Europe. Usually microsatellite markers developed and discovered in Oryctolagus cuniculus, are markers of choice in population genetic,

\footnotetext{
${ }^{1}$ Djan M., Veličković N., Stefanović M., Obreht Vidaković D, Vapa Lj., Department of Biology and Ecology, Faculty of Sciences, University of Novi Sad, Serbia

${ }^{2}$ Marković V., Department of Geography, Tourism and Hotel Management, Faculty of Sciences, University of Novi Sad, Serbia Corresponding author: Mihajla Djan: Mihajla.djan@dbe.uns.ac.rs
} 
studies of hares. Mougel et al. (1997) developed six new microsatellite markers in populations of wild rabbits and confirmed the usefulness of the three previously described by Rico et al. (1994) for genotyping hares. In the analysis of $L$. europaeus populations among these microsatellites, three proved to be particularly informative: Sat2, Sat5 and Sat12 (Mougel et al., 1997). Additional six new microsatellite markers detected in rabbits Oryctolagus cuniculus (Surridge et al., 1997), proved to be applicable in 20 different taxa of Lagomorpha. The developed markers were employed for analysis of population diversity and structure and possible hybridization between L. europaeus and L. timidus in Scandinavian Peninsula (Andersson et al., 1999; Thulin et al., 2006a). Estimated genetic differentiation between species was low and authors suggested reticular evolution of these species, with a constant gene flow between them. Information provided by the microsatellites showed clear genetic differentiation and distinctiveness among L. europaeus, L. castroviejoi, and L. granatensis in the Iberian Peninsula (Estonba et al., 2006), and moderately high genetic diversity of Lepus europaeus populations. The comprehensive study by Fickel et al. (2005) of brown hare populations in Germany detected a high degree of genetic variability, matrilinearily structured populations, male-biased gene flow, and lack of inbreeding. No geographical or anthropogenic barriers to gene flow were found. Ben Slimen et al. (2008) reported decrease of intraspecific genetic diversity in $L$. capensis and L. europaeus in south-north direction, from South Africa, North Africa, Israel, Anatolia, the Balkans, central Europe to north western Europe.

So far, only partial information about the population structure of brown hares (Lepus europaeus) from Serbia is available, despite the large amount of studies of brown hares populations structure from Europe. In previous studies, the allozyme composition of brown hares from Vojvodina (northern province in Serbia) were analyzed (Vapa et al., 2002, 2007; Djan et al., 2013), indicating very similar allele composition to brown hares from other parts of central Europe. Also, the analyses of mtDNA polymorphism in brown hares from Vojvodina province (Djan et al., 2006; Stamatis et al., 2009) adjoins the populations to the central European brown hare haplotype group. Different local hare populations from Europe have already been analyzed using microsatellites (Andersson et al., 1999; Fickel et al., 2005; Estonba et al., 2006; Ben Slimen et al., 2008), but from the Central Balkan region only brown hare population from Vojvodina was characterized using microsatellites (Djan et al., 2013).

Awarness of the value of genetic resources has encouraged studies of the genetic diversity present in different game populations. Game population genetic structure has important ecological and evolutionary consequences, but also precise knowledge on population structure is required for maintaining its economic value, because management plans could be designed for particular population. Usually, population genetic studies focus on fragmented populations, endangered species or on species with complex social systems. Lower number of investigations deals with the analyses of genetic structure in continuously distributed species, such as brown hares. Considering all available facts, in this study we aim to detect population genetic diversity and structure in brown hares from Serbia using microsatellites in order to reveal genetic diversity of previously unsampled population and define population genetic structure. Obtained data could be useful in future brown hare management plans and relevant for sustainability of brown hare populations in the Balkans.

\section{Sample collection}

\section{Material and Methods}

A total number of 157 brown hares were collected from six different regions in Serbia, during hunting seasons from 2004 to 2006. The following 6 regions, subsequently termed "groups", were included in genetic analyses: Bačka (26), Banat (26), Srem (26), Northern-Central (NC) Serbia (32), Norther-Eastern (NE) Serbia (13) and Northern-Western (NW) Serbia (34) (numbers of samples per group are given in parenthesis) (Fig. 1), not only due to geographic proximity, but also considering biogeographical features of the areas. Sampled tissue was frozen immediately after death of animal. 


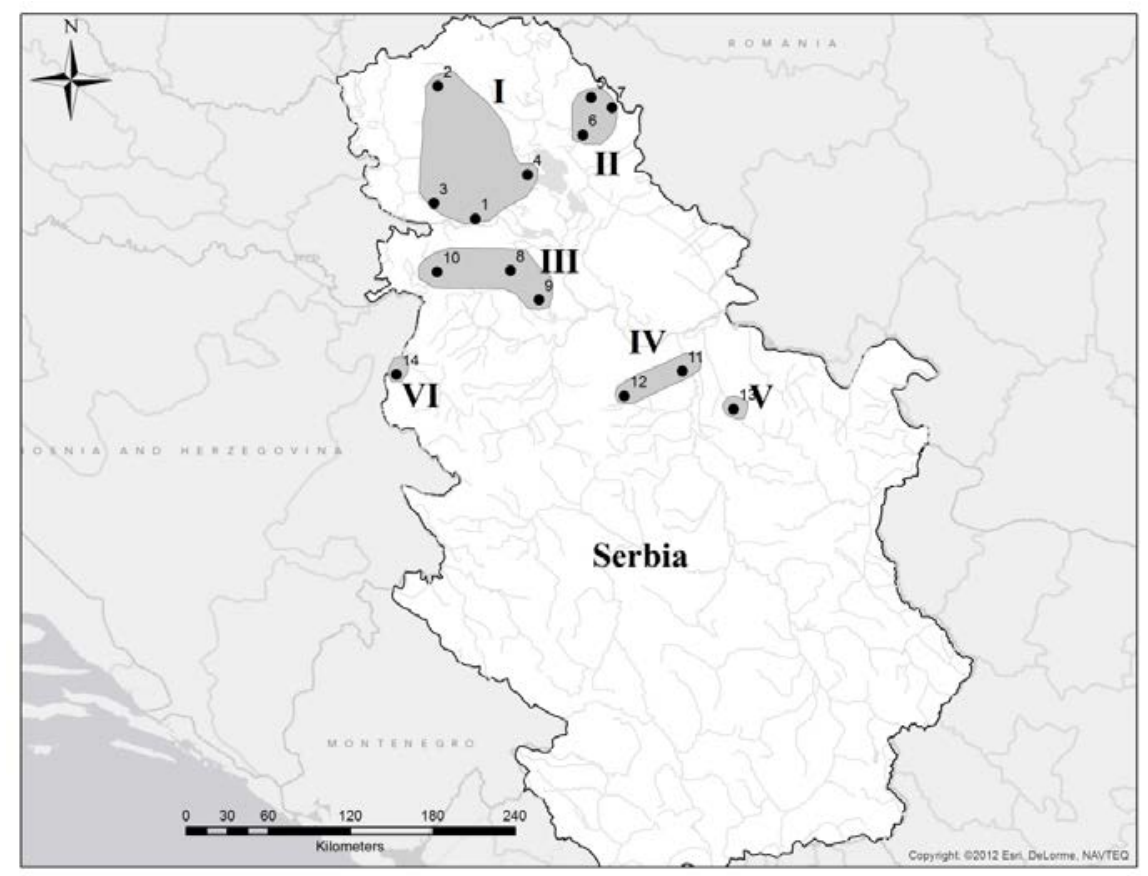

Figure 1. Map of sampling regions. I - Bačka (1-Futog; 2 - Stara Moravica; 3 - Nova Gajdobra; 4 - Čurug); II - Banat (5 - Kikinda; 6 - Bašaid; 7 - Novi Kozarci); III - Srem (8 - Žarkovac; 8 - Krnješevci; 10 Martinci); IV - Northern-Central Serbia (11 - Osipaonica; 12 - Mladenovac); V - Northern-Eastern Serbia (13 - Petrovac na Mlavi); VI - Nothern-Western Serbia (14 - Loznica)

\section{Microsatellite analysis}

Total DNA was extracted from liver, tongue and eye tissue using standard phenol chloroform isoamylalcohol extraction with proteinase K digestion (Sambrook and Russel, 2001).

Six microsatellite loci with different levels of polymorphism were analyzed: Sat2, Sat5, Sat12 (Mougel et al., 1997), Sol33 (Surridge et al., 1997), and Lsa2 and Lsa3 (Kryger et al., 2002). Due to relatively small sample sizes of certain populations, microsatellite markers with varying levels of polymorphism were selected in order to outbalance the fact, as suggested by Shriver et al. (1995) and Takezaki and Nei (1996).

All reactions were performed in $20 \mu \mathrm{l}$ volume. The PCR reactions contained 100ng of DNA template, 1 BBuffer (with $15 \mathrm{mM} \mathrm{MgCl}_{2}$ ), $200 \mu \mathrm{M}$ dNTPs, 10 pmol of each primer, $1 \mathrm{mM} \mathrm{MgCl}_{2}$ and 1 unit of Taq DNA polymerase. The PCR conditions with optimized annealing temperatures for each locus are given in Table 1.

Table 1. PCR conditions with optimized annealing temperatures for amplification of microsatellites in brown hares

\begin{tabular}{|l|l|l|}
\hline Locus & PCR conditions ${ }^{\circ} \mathrm{C}(\mathrm{s})$ & Reference \\
\hline Sat2 & $95(120), 25 \times$ [94 (30), $55(60), 72(120)], 72(600)$ & Mougel et al., 1997 \\
\hline Sat5 & $95(120), 25 \times[94(30), 58(60), 72(120)], 72(600)$ & Mougel et al., 1997 \\
\hline Sat12 & $95(120), 25 \times[94(30), 55(60), 72(120)], 72(600)$ & Mougel et al., 1997 \\
\hline Sol33 & $94(180), 7 \times$ x [94 (30), 52 (30), 72 (30)], 23 x [89 (30), 52 (30), 72 (30)] & Surridge et al., 1997 \\
\hline Lsa2 & $94(180), 35 \times[94(30), 57(30), 72(30)]$ & Kryger et al., 2002 \\
\hline Lsa3 & $94(180), 35 \times[94(30), 56(30), 72(30)]$ & Kryger et al., 2002 \\
\hline
\end{tabular}

The PCR products of loci Sat2, Sat5, Sat12, Sol33, Lsa2 and Lsa3 were applied to a $2 \%$ agarose gels, stained with ethidium bromide and fragments were visualized under UV light. Samples that were successfully amplified for the fragments of interest, were electrophoretically separated by applying $5 \mu$ of each to a $6 \%$ denaturing polyacrylamide gel with $1 \mathrm{xTBE}$ buffer, followed by silver staining in order to visualize the PCR products. A known DNA molecular weight-size marker was run with the PCR products to 
measure the size of different alleles. The individuals that failed to produce signal were amplified a second time, under the same conditions.

\section{Data analysis}

All brown hare samples were divided into 6 groups based on their geographic proximity: (1) Backa, (2) Banat, (3) Srem, (4) Northern-Central Serbia, (5) Northern-Eastern Serbia, and (6) Northern-Western Serbia (Fig. 1). The analysis of molecular variance (AMOVA) and pairwise genetic distances among the presumed groups $\left(\mathrm{F}_{\mathrm{ST}}\right)$ were calculated using ARLEQUIN 3.5.1.2 (Excoffier \& Lischer, 2010). Significance levels were adjusted using the sequential Bonferroni correction for multiple comparisons (Rice, 1989). In order to infer the existence of population structuring of brown hares in Serbia, Bayesian cluster analyses implemented in STRUCTURE 2.3.3 (Pritchard et al., 2000; Falush et al., 2003, 2007; Hubisz et al., 2009) were performed. STRUCTURE run was performed assuming admixture model with correlated allele frequencies with burn-in length of 100,000 followed by 1,000,000 MCMC (Markov Chain Monte Carlo) iterations. For the estimation of the most likely number of clusters and graphical interpretation of the results we used CLUMPAK (Kopelman et al., 2015). Genetic similarity among individual genotypes were also examined through factorial correspondence analysis using GENETIX (Belkhir et al., 2004).

Microsatellite loci were tested for deviation from Hardy-Weinberg equilibrium (HWE) and genotypic linkage disequilibrium using ARLEQUIN in inferred genetic clusters (subpopulations). The same program was used to calculate mean number of alleles (A), observed (Ho) and expected (He) heterozygosities and inbreeding coefficients for each locus and for each defined subpopulation. The amount of partitioning of nuclear diversity among subpopulations was calculated by AMOVA model using the ARLEQUIN and pairwise genetic distances among the inferred subpopulations $\left(\mathrm{F}_{\mathrm{ST}}\right)$ was also estimated.

Detection of migrants and hybrids between subpopulations was performed using computer package NEWHYBRIDS 1.0 (Anderson and Thompson, 2002). This analysis included all individuals that were analyzed for hybrid or parental origin. The analysis was performed in 3 replicas with burn in length of 50,000 followed by 100,000 MCMC iterations. In order to infer demographic history of brown hare populations from Serbia bottleneck analysis was carried out for each defined subpopulation using program BOTTLENECK (Cornuet and Luicart, 1997). We performed analysis considering two-phase model of microsatellite evolution set with $90 \%$ of mutations following the strict stepwise mutation model and $10 \%$ being multistep mutations. The results obtained for each locus were combined using the Wilcoxon test.

\section{Results}

Genotyping of all 157 brown hare specimens was successful for locus Sat2 (100\%), while amplification success rate in the remaining loci ranged from $98.73 \%$ for the locus Sol33 to $87.9 \%$ for the locus Lsa2. Unsuccessful amplifications for certain samples might be consequence of null alleles that occur mostly due to mutations in primer binding region, but we cannot exclude another possible cause of inhibition of PCR reactions in individual samples.

For the initial analysis of the brown hare population structure from Serbia pairwise genetic distances among six presumed groups $\left(\mathrm{F}_{\mathrm{ST}}\right)$ were calculated (Table 2.). The sampling group Northern-Western Serbia showed statistically significant genetic differentiation from all other sampling groups. Furthermore, AMOVA among six sampling groups showed $10.76 \%$ of variation among groups $(\mathrm{p}<0.0001)$ and $89.24 \%$ within groups.

Table 2. Relative genetic differentiation between 6 presumed brown hares groups from Serbia based on pairwise $\mathrm{F}_{\mathrm{ST}}$ (below diagonal) and number of shared alleles (above diagonal)

\begin{tabular}{|l|l|l|l|l|l|l|}
\hline & Backa & Banat & Srem & NC Serbia & NE Serbia & NW Serbia \\
\hline Backa & & 43 & 37 & 37 & 25 & 18 \\
\hline Banat & 0.000 & & 41 & 43 & 31 & 22 \\
\hline Srem & 0.020 & 0.013 & & 40 & 30 & 18 \\
\hline Central Serbia & 0.027 & 0.021 & 0.022 & & 25 & 21 \\
\hline Eastern Serbia & 0.025 & 0.009 & 0.018 & 0.013 & & 14 \\
\hline Western Serbia & $0.191^{*}$ & $0.207^{*}$ & $0.261^{*}$ & $0.210^{*}$ & $0.282^{*}$ & \\
\hline
\end{tabular}

${ }^{*} \mathrm{p}<0.05$ (0.008 after Boniferroni correction) 
Following the $\Delta \mathrm{K}$ method, the most likely number of distinct genetic clusters was $\mathrm{K}=2$ (Fig. 2). Bayesian approach implemented in the STRUCTURE revealed that the overall data set was most likely representing 2 genetic subunits (i.e., subpopulations).

First subpopulation, named Northern-Central-Eastern (NCE) Serbia consists of five initially defined groups (Backa, Banat, Srem, NC Serbia and NE Serbia) while second subpopulation comprised of individuals from Northern-Western (NW) Serbia. Observed population genetic structure was further supported by Factorial Correspondence Analysis (Fig. 3.) with clear separation of individuals from NW Serbia.

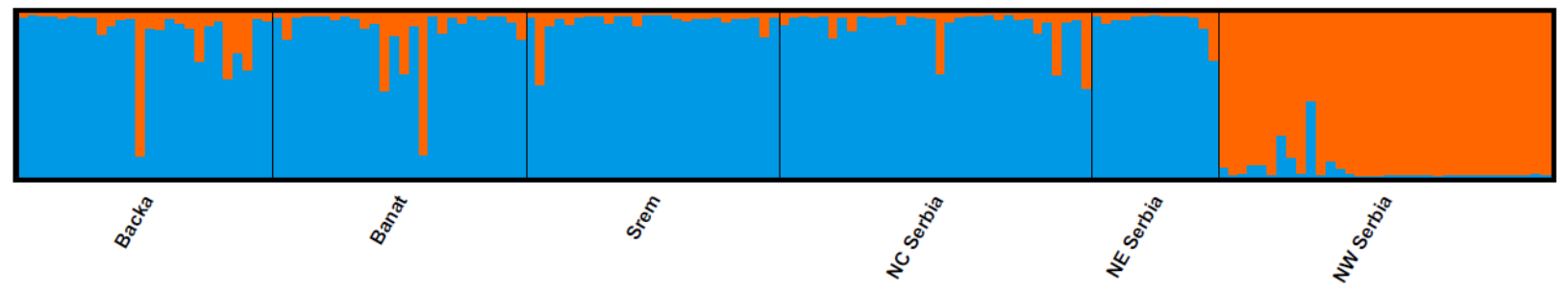

Figure 2. Estimated population structure of brown hare (Lepus europaeus) from Serbia. Each individual is represented by a vertical line, a thick black lines separate individuals from different sampling groups. Different colors represent different posterior probability of assignment of each individual to each of the inferred genetic clusters

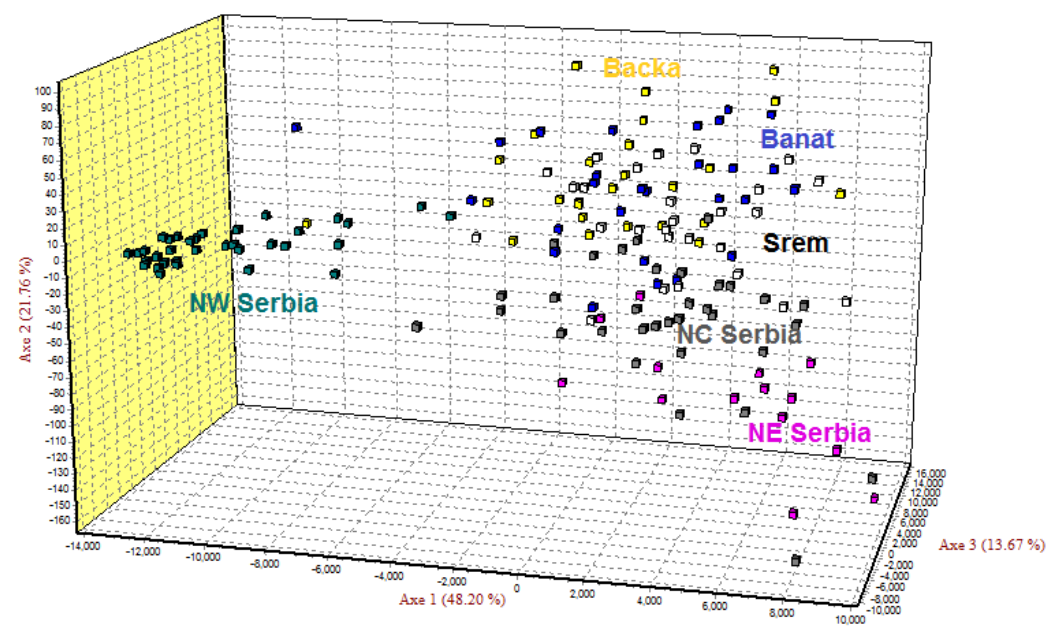

Figure 3. 3D Factorial Correspondence Analysis performed for 157 brown hares from Serbia.

Parameters of genetic variability were calculated for inferred genetic clusters (subpopulations). A total number of 81 alleles at 6 loci were found in brown hare populations from Serbia. The highest number of alleles per locus was found at Lsa2 microsatellite loci (20), while the lowest number of alleles was present at loci Sat5 and Lsa3 (9), with an average of 13.5 alleles/locus in total sample.

All six analyzed microsatellites were polymorphic in NCE Serbia subpopulation, and four were polymorphic in NW Serbia subpopulation (Table 3).

Observed heterozygosity (Ho) value was higher in NCE Serbia subpopulation (0.530) compared to NW Serbia subpopulation (0.470). The highest observed heterozygosity was found for locus Lsa2 in both subpopulations, and the lowest at locus Lsa3. Deviation from Hardy-Weinberg equilibrium was found in all loci for NCE Serbia subpopulation, and for three (Sat2, Lsa2, Lsa3) out of four polymorphic loci in NW Serbia subpopulation (Tab. 3). No genetic signature of recent bottleneck was detected for any subpopulation, but heterozygote deficiency was detected in NW subpopulation ( $\mathrm{p}=0.03125)$. 
Table 3. Allelic variation at 6 microsatellite loci in two brown hare (Lepus europaeus) subpopulations in Serbia

\begin{tabular}{|c|cccccc|cccccc|}
\hline \multirow{2}{*}{ Locus } & \multicolumn{5}{|c|}{ NCE Serbia subpopulation } & \multicolumn{4}{c|}{ NW Serbia subpopulation } \\
\cline { 2 - 8 } & 2n & Na & AP & Ho & He & Fis & 2n & Na & AP & Ho & He & Fis \\
\hline Sat2 & 246 & 19 & 12 & 0.715 & 0.920 & 0.223 & 66 & 6 & 0 & 0.424 & 0.656 & 0.357 \\
Sat5 & 216 & 9 & 8 & 0.167 & 0.657 & 0.743 & $/$ & 1 & 0 & $/$ & $/$ & $/$ \\
Sat12 & 224 & 12 & 6 & 0.777 & 0.851 & 0.087 & 62 & 7 & 1 & 0.548 & 0.716 & 0.238 \\
Sol33 & 242 & 11 & 10 & 0.430 & 0.641 & 0.331 & $/$ & 1 & 0 & $/$ & $/$ & $/$ \\
Lsa2 & 210 & 20 & 15 & 0.847 & 0.913 & 0.072 & 64 & 5 & 0 & 0.687 & 0.528 & -0.309 \\
Lsa3 & 220 & 9 & 5 & 0.245 & 0.769 & 0.682 & 64 & 4 & 0 & 0.219 & 0.428 & 0.493 \\
\hline Mean & 226.3 & 13.3 & 9.3 & 0.5 & 0.8 & 0.3 & 64 & 5.5 & 0.2 & 0.5 & 0.6 & 0.2 \\
\hline
\end{tabular}

$2 \mathrm{n}$ - total number of alleles/sample size; $\mathrm{Na}$ - numer of alleles per locus; AP - number of private alleles; Ho - observed heterozygosity; He - expected heterozygosity; Fis - inbreeding coefficient

Seven pairs of loci (out of 15 combinations) were in linkage disequilibrium in NCE Serbia subpopulation, and none pair of loci showed linkage disequilibrium in NW Serbia subpopulation. The pairwise genetic differentiation was high $\mathrm{F}_{\mathrm{ST}}=0.168(\mathrm{p}<0.0001)$. Analysis of molecular variance showed higher intrapopulation variability (81.12\%) comparing to interpopulation variability $(18.88 \%)(\mathrm{p}<0.001)$, which was statistically significant and high (Table 4).

Table 4. Partioning of nuclear diversity among brown hare subpopulations from Serbia by AMOVA model

\begin{tabular}{|l|l|l|l|}
\hline Source of variation & Sum of squares & Variance components & \% variation \\
\hline Among subpopulations & 51.388 & 0.48869 & 18.88 \\
\hline Within subpopulations & 607.466 & 2.09975 & 81.12 \\
\hline
\end{tabular}

The NEWHYBRIDS analyses matched genotype-based assignment of individuals and it was shown that two subpopulations defined in Bayesian cluster analysis represent two parental populations (Fig. 4). We didn't find migrants between these two subpopulations, while we found presence of F2 hybrids in each subpopulation. Higher number of F2 hybrids was observed in NCE Serbia subpopulation.

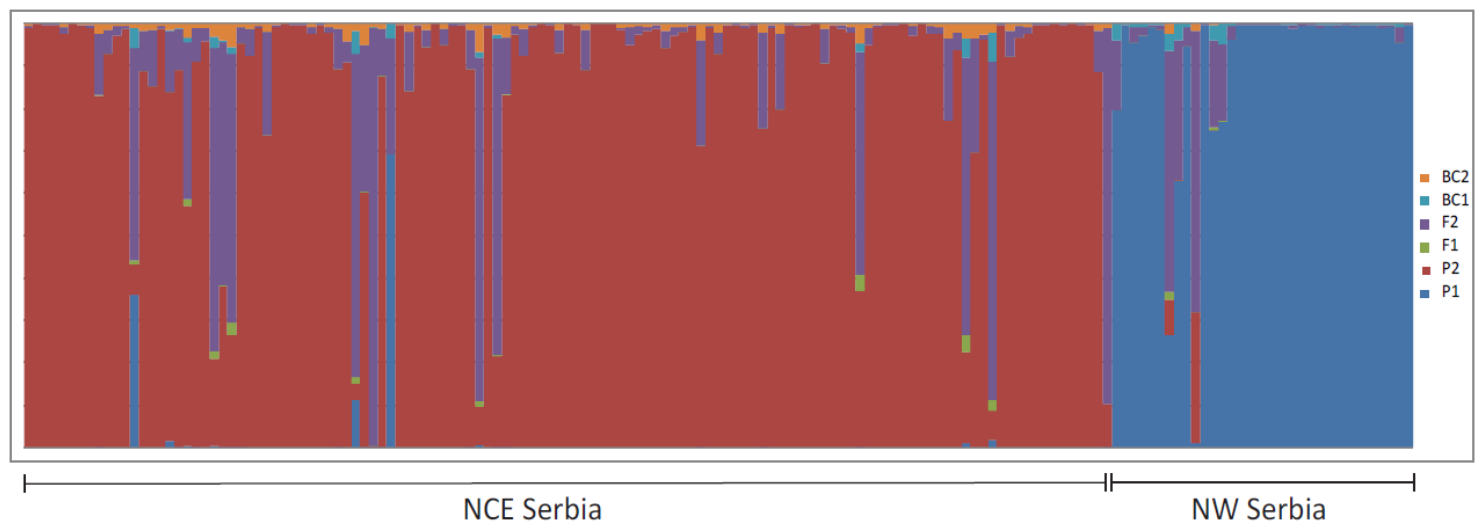

Figure 4. Results of the pairwise analysis for parental or hybrid origin of individuals from the two brown hare subpopulations in Serbia, preformed with NEWHYBRIDS. Posterior probabilities of assignment to parental and hybrid classes are plotted in different colours.

\section{Discussion}

Advancements in molecular techniques constantly provide novel methods for rapid and reliable genotyping of animal natural populations. So far, genetic diversity of brown hare populations from Serbia was analyzed by detection of allozyme variability levels (Vapa et al., 2007). Moreover, previous studies were dealing with the analyses of genetic diversity of brown hare populations from Vojvodina (Vapa et al., 2002; Djan et al., 2006; Vapa et al., 2007; Djan et al., 2013), but no data were published on genetic variability of brown hare populations from other regions in Serbia using microsatellites or other nuclear 
DNA markers. Previous studies based on analyses of CR-1 mtDNA sequence variability indicated possible structuring of brown hares from Serbia (Djan et al., 2006; Stamatis et al., 2009).

An average number of alleles per locus in our study was lower than detected in $L$. europaeus and $L$. capensis populations (14.7 alleles/locus) (Ben Slimen et al., 2008) and Scandinavian hares (16.3) (Thulin et al., 2006b), but higher than in Canadian snowshoe hares (13.4) (Burton et al., 2002) and brown hare populations from Germany (11.2) (Fickel et al., 2005). Observed differences might be due to number of individuals analysed, more restricted sampling area in our study or different set of microsatellite markers employed. Observed heterozygosity of the brown hare populations from Serbia was within the range found for the Central European populations (Fickel et al., 2005, Ben Slimen et al., 2008) and Scandinavian brown hares (Andersson et al., 1999).

A combined statistical analyses of the presently produced allele set suggested genetic differentiation of brown hare sample into two defined subpopulations: Northern-Central-Eastern Serbia (NCE) and Northern-Western (NW) Serbia. Heterozygosity values indicated that brown hares from this subpopulation are still sufficiently genetically diverse to avoid inbreeding depression and to exclude fixation of alleles. Observed significant deviations from the Hardy-Weinberg equilibrium (HWE) in all loci may suggest a high level of gene exchange among European brown hares from NCE and NW Serbia subpopulations and possibly unsampled neighbouring brown hare subpopulations. Moreover, NEWHYBRIDS results showed present but restricted gene flow between NCE Serbia and NW Serbia subpopulations. It was shown that higher number of F2 hybrids is present in NCE Serbia subpopulation and this indicates existance of gene flow between brown hares from NCE and NW Serbia, but also gene flow with a non sampled populations from neighbouring countries can not be excluded. In order to further speculate on reasons for the observed restricted gene flow, individuals from a broader sampling area should be analysed, specifically from Southern Serbia. Deviation from Hardy-Weinberg equilibrium was also found in majority of L. europaeus populations in Europe (Ben Slimen et al., 2008). Heterozygote deficiency detected in NW Serbia subpopulation may be caused by inbreeding or might be also explained by Wahlund effect, which is unlikely for our data. In Scandinavian hares heterozygote deficiency was detected in all populations (Andersson et al., 1999; Thulin et al., 2006b).

Genetic variation within subpopulations was much higher as among subpopulations, indicating probably successful reproductive activity by many females. According to Fickel et al. (2005) genetic variation within brown hare populations from Germany was twice higher as among populations. This ratio in our study was much higher, as well as in Ben Slimen et al. (2008).

It could be concluded that microsatellites revealed high genetic differentiation of brown hares from Serbia into two subpopulations, as it was previously slightly suggested by allozyme and mtDNA variability analyses (Vapa et al., 2002, 2007; Djan et al., 2006, 2013). Earlier studies show that there is in general moderate gene pool divergence among the brown hare populations in Europe and moderately reduced gene flow across longer geographic distances (Hartl et al., 1993; Mamuris et al., 2001; Vapa et al., 2002, 2007). Observed differentiation should be considered in future brown hare management strategies, in order to preserve existing genetic diversity and to avoid further reduction of genetic variability in Northern-Western Serbia subpopulation or human mediated admixtures which can disturb present gene pools. The detection of distinct gene pools (and in a sense, different random mating units) in Serbian brown hare populations can provide important insight for the management. As game species, hares are subjected to exploitation and management, not always following the best practices and integrated approaches. We believe that genetic population structure information should be integrated with other traditional methods for brown hare hunting management strategy (such as estimation of population size and age structure), in order to provide long-term sustainability of the population.

\section{References}

1. Anderson EC, Thompson EA. (2002) A model-based method for identifying species hybrids using multilocus genetic data. Genetics 160: 1217-1229

2. Andersson AC, Thulin CG, Tegelstrom H. (1999) Applicability of rabbit microsatellite primers for studies of hybridization between an introduced and a native hare species. Hereditas 130: 309-315

3. Belkhir K, Borsa P, Chikhi L, Raufaste N, Bonhomme F. (2004) GENETIX V. 4.0, logiciel sous WindowsTM pour la génétique des populations. Laboratoire Génome, Populations, Interactions CNRS UMR 5000, Université de Montpellier II, Montpellier, France. 
4. Ben Slimen H, Suchentrunk F, Memmi A, Sert H, Kryger U, Alves PC, Ben Ammar Elgaaied A. (2006) Evolutionary relationships among hares from North Africa (Lepus sp. or Lepus spp.), cape hares (L. capensis) from South Africa, and brown hares (L. europaeus), as inferred from mtDNA PCR-RFLP and allozyme data. Journal of Zoological Systematics and Evolutionary Research 44: 88-99

5. Ben Slimen H, Suchentrunk F, Shahin AAB, Ben Ammar Elgaaied A. (2007) Phylogenetic analysis of mtCR-1 sequences of Tunisian and Egyptian hares (Lepus sp. or spp., Lagomorpha) with different coat colours. Mammalian Biology 72: 224239.

6. Ben Slimen H, Suchentrunk F, Stamatis C, Mamuris Z, Sert H, Alves CP, Kryger U, Shanin AB, Elgaaied ABA. (2008) Population genetics of cape and brown hares (Lepus capensis and L. europaeus): A test of Petter 's hypothesis of conspecificity. Biochemical Systematics and Ecology 36: 22-29

7. Burton C, Krebs JC, Taylor BE. (2002) Population genetic structure of the cyclic snowshoe hare (Lepus americanus) in southwestern Yukon, Canada. Molecular Ecology 11: 1689-1701

8. Cornuet JM, Luikart G. (1997) Description and Power Analysis of Two Tests for Detecting Recent Population Bottlenecks from Allele Frequency Data. Genetics 144(4): 2001-2014

9. Djan M, Obreht D, Vapa LJ. (2006) Polymorphism of mtDNA regions in brown hare (Lepus europaeus) populations from Vojvodina (Serbia and Montenegro). European Journal of Wildlife Research 52: 288-291

10. Djan M, Popović D, Veličković N, Obreht D, Vapa Lj. (2013) Comparison of allozyme and microsatellite variability in brown hare populations (Lepus europaeus Pallas) from Vojvodina (Serbia). Biologia Serbica 35(1-2): 24-30

11. Estonba A, Solis A, Iriondo M, Sanz-Martin JA, Perez-Suarez G, Markov G, Palacios F. (2006) The genetic distinctiveness of the Iberian hare species: Lepus europaeus, L. granatensis and L. castroviejoi. Mammalian Biology 71 (1): $52-59$

12. Excoffier L, Lischer H.E. (2010) Arlequin suite ver 3.5: A new series of programs to perform population genetics analyses under Linux and Windows. Molecular Ecology Resources 10: 564-567

13. Falush D, Stephens M, Pritchard JK. (2003) Inference of population structure using multilocus genotype data: linked loci and correlated allele frequencies. Genetics 164(4): 1567-1587

14. Fickel J, Schmidt A, Putze M, Spittler H, Ludwig A, Streich JW, Pitra C. (2005) Genetic structure of populations of European brown hare: implications for management. Journal of Wildlife Management 69 (2): 760-770

15. Hartl GB, Suchentrunk F, Nadlinger K, Willing R. (1993) An integrative analysis of genetic differentiation in the brown hare Lepus europaeus based on morphology, allozymes and mitochondrial DNA. Acta theriologica 38, Suppl. 2: 33-57

16. Hubisz M, Falush D, Stephens M, Pritchard JK. (2009) Inferring weak population structure with the assistance of sample group information. Molecular Ecology Resources 9(5): 1322-1332

17. Kasapidis P, Suchentrunk F, Magoulas A, Kotoulas G. (2005) The shaping of mitochondrial DNA phylogeographic patterns of the brown hare (Lepus europaeus) under the combined influence of Late Plaistocene climatic Fluctuations and anthropogenic translocations. Molecular Phylogenetics and Evolution 34: 55-66

18. Kopelman NM, Mayzel J, Jakobsson M, Rosenberg NA, Mayrose I. (2015) Clumpak: a program for identifying clustering modes and packaging population structure inferences across K. Molecular Ecology Resources doi: 10.1111/17550998.12387. [Epub ahead of print]

19. Kryger U, Robinson TJ, Bloomer P. (2002) Isolation and characterization of six polymorphic microsatellite loci in South African hares (Lepus saxatilis F. Cuvier, 1823 and Lepus capensis Linnaeus, 1758). Molecular Ecology Notes 2: 422-424

20. Mamuris Z, Sfougaris AI, Stamatis C. (2001) Genetic structure of Greek brown hare (Lepus europaeus) populations as revealed by mtDNA RFLP-PCR analysis implications for conserving genetic diversity. Biological Conservation 101: $187-$ 196

21. Mougel F, Mounolou JC, Monnerot M. (1997) Nine polymorphic microsatellite loci in the rabbit, Oryctolagus cuniculus. Animal Genetics 28: 58-71

22. Pritchard JK, Stephens M, Donnelly P. (2000) Inference of Population Structure Using Multilocus Genotype Data. Genetics 155: 945-959

23. Rice WR. (1989) Analyzing tables of statistical tests. Evolution 43: 223-225

24. Rico C, Rico I, Webb N. (1994) Four polymorphic microsatellite loci for the European Wild Rabbit, Oryctolagus cuniculus. Animal Genetics 25: 367

25. Robinson TJ, Elder FFB, Chapman JA. (1983) Karyotypic conservatism in the genus Lepus (order Lagomorpha). Canadian Journal of Genetics and Cytogenetics 25: 540-544

26. Sambrook JF, Russel DW. (2001) Molecular Cloning: A laboratory manual, 3rd Edition. Cold Sprin Harbour Laboratory Press, USA

27. Shriver MD, Jin L, Boerwinkle E, Deka R, Ferrel RE, Chakraborty R. (1995) A novel measure of genetic distance for highly polymorphic tandem repeat loci. Molecular Biology and Evolution 12: 914-920

28. Stamatis C, Suchentrunk F, Moutou K, Giacometti M, Haerer G, 4, Djan M, Vapa Lj, Vukovic M, Tvrtković N, Sert H, Paulo A, Mamuris Z. (2009) Phylogeography of the brown hare (Lepus europaeus) in Europe: a legacy of south-eastern Mediterranean refugia? Journal of Biogeography 36(3): 515-528

29. Suchentrunk F, Polster K, Giacometti M, Ratti P, Thulin CG, Ruhlé C, Vasil'ev AG, Slotta-Bachmayr L. (1999). Spatial partitioning of allozyme variability in European mountain hares (Lepus timidus): gene pool divergence across a disjunct distributional range? Zeitschrift für Säugetierkunde 64: 1-11

30. Suchentrunk F, Michailov C, Markov G, Haiden A. (2000) Population genetics of Bulgarian brown hares Lepus europaeus: allozymic diversity at zoographical crossroads. Acta theriologica 45: 1-12

31. Suchentrunk F, Mamuris Z, Sfougaris A, Stamatis C. (2003) Biochemical genetic variability in brown hares (Lepus europaeus) from Greece. Biochemical Genetics 41 (5/6): 127-140 
32. Surridge AK, Bell DJ, Rico C, Hewitt GM. (1997) Polymorphic microsatellite loci in the European rabbit (Oryctolagus cuniculus) are also amplified in other lagomorph species. Animal Genetics 28: 302-305

33. Takezaki N, Nei M. (1996) Genetic distances and reconstruction of phylogenetic trees from microsatellite DNA. Genetics 144: 389-399

34. Thulin GC, Jaarola M, Tegelström H. (1997) The occurence of mountain hare mitochondrial DNA in wild brown hares. Molecular Ecology 6: 463-467

35. Thulin CG, Fang M, Averianov AO. (2006a) Introgression from Lepus europaeus to L. timidus in Russia revealed by mitochondrial single nucleotide polymorphisms and nuclear microsatellites. Hereditas 143: 68-76

36. Thulin CG, Stone J, Tegelstrom H, Walker WC. (2006b) Species assignment and hybrid identification among Scandinavian hares Lepus europaeus and L. timidus. Wildlife Biology 12(1): 29-38

37. Vapa Lj, Obreht D, Vapa M, Selmic V. (2002) Genetic variability in brown hare (Lepus europaeus) populations in Yugoslavia. Zeitschrift Fur Jagdwissenschaft 48: 261-266

38. Vapa Lj, Djan M, Obreht D, Hammer S, Suchentrunk F. (2007) Allozyme variability of brown hares (Lepus europaeus) from the Vojvodina (Serbia), compared to central and south eastern European populations. Acta Zoologica Academiae Scientiarum Hungaricae 53: 75-87

Received: 29.03.2015.

Accepted:20.07.2015.

Djan M., Veličković N., Stefanović M., Marković V., Obreht Vidaković D., Vapa Lj. (2015). Genetic variation within and among brown hare (Lepus europaeus Pallas, 1778) populations in Serbia as inferred from microsatellites), Balkan Journal of Wildlife Research, 2(2), pp. 18-26. 